\title{
Overlap of dietary niche and electivity of three shrimp species (Crustacea, Decapoda) in a tropical coastal lagoon (Rio de Janeiro, Brazil)
}

\author{
Edélti Faria Albertoni ${ }^{1,3}$, Cleber Palma-Silva ${ }^{1} \&$ Francisco de Assis Esteves ${ }^{2}$
}

\author{
${ }^{1}$ Laboratório de Ecologia, Departamento de Ciências Morfo-Biológicas, Fundação Universidade Federal do Rio Grande. \\ Avenida Itália Km 8, 96201-900 Rio Grande, Rio Grande do Sul, Brasil. E-mail: dmbefa@furg.br \\ 2 Departamento de Ecologia, Universidade Federal do Rio de Janeiro. Ilha do Fundão, 21941-540 Rio de Janeiro, Rio de \\ Janeiro, Brasil. \\ ${ }^{3}$ Corresponding author.
}

\begin{abstract}
Three species of shrimp, Farfantepenaeus brasiliensis (Latreille, 1817), F. paulensis (Pérez-Farfante, 1967) (Penaeidae) and Macrobrachium acanthurus (Wiegmann, 1836) (Palaemonidae) were sampled at the Imboassica lagoon (Rio de Janeiro State, Brazil), in order to estimate the overlap of dietary niches and electivity of their prey, through the analysis of the fauna associated with the macroalgae Chara and of the benthic fauna on the sediment. The overlap of dietary niches was estimated using five indexes. A total of $495 \mathrm{~F}$. brasiliensis, $131 \mathrm{~F}$. paulensis and $102 \mathrm{M}$. acanthurus stomachs were examined. The results of the different indexes of niche overlap exhibited the same general trend in the three species, indicating a high degree of homogeneity in the diet of the two species of Penaeidae (between 75 and 100\%) and a smaller overlap between each Penaeidae species and M. acanthurus (between 23 and 68\%). The species presented selective predation, with differences in the two studied habitats. The results show that the three species are omnivorous, with a varied diet including components of benthic macrofauna and those associated with the macroalgae Chara, plant fragments and detritus, and that there are good conditions in the Imboassica lagoon for the development of these species.
\end{abstract}

KEY WORDS. Feeding, Farfantepenaeus brasiliensis, Farfantepenaeus paulensis, Macrobrachium acanthurus, stomach contents.

Coastal lagoons in tropical areas are traditionally places used for fishing, which has been primary food source for many towns and cities. However, over the last few decades human activities have intensified, resulting in serious damage to the natural systems (Branco et al. 1997). In spite of the fact that these areas constitute important sites for traditional subsistence fishing, little information is available about the biology and ecology of the main organisms exploited.

It is important to know an animal's diet in its habitat in order to be aware of its nutritional needs and its interaction with other organisms. For this reason, studies to evaluate the gut content try to identify and quantify the resources that a species uses, providing information on those selected from the choices available in the environment (WILLIAMS 1981; TARARAM et al. 1993). The concept of niche overlap plays an important role in community theory (LAWLOR 1980). In studies of species interaction and community structure, it is useful to quantify the degree to which two species overlap in their utilization of space, food or other resources, and several measures of niche overlap have been proposed (HuRlBert 1978).
The Crustacean decapods have been recognized by many authors as important predators in tropical coastal environments (Nelson 1981; Leber 1985; Preston et al. 1992; Heales et al. 1996, among other). In general, areas colonized by aquatic vegetation are important habitats for these organisms, providing refuge and food, by virtue of the fauna associated to the aquatic macrophytes. They are important predators in habitats with vegetation, and a shrimp's diet presents high proportions of epifauna such as small crustaceans, molluscs and Polychaeta (LEBER 1985).

The aim of this work is to interpret the trophic relationships of three species of Decapoda from the Imboassica lagoon, Farfantepenaeus brasiliensis (Latreille, 1817), F. paulensis (PérezFarfante, 1967) (Penaeidae) and Macrobrachium acanthurus (Wiegmann, 1836) (Palaemonidae), through the evaluation of the alimentary niche overlap between these species and their diet electivity.

Imboassica is a coastal lagoon located in the municipality of Macaé $\left(22^{\circ} 30^{\prime} \mathrm{S}\right.$ and $\left.42^{\circ} 00^{\prime} \mathrm{W}\right)$, Rio de Janeiro State, Brazil. The regional climate is subhumid, with a maximum mean 
temperature of $29.9^{\circ} \mathrm{C}$ in February (summer) and a minimum mean temperature of $25.4^{\circ} \mathrm{C}$ in July (winter). Annual precipitation varies between $800 \mathrm{~mm}$ and $1200 \mathrm{~mm}$ (RADAMBRASIL 1983). It is a shallow environment, with an area of $3.26 \mathrm{~km}^{2}$ and an average depth of $1.1 \mathrm{~m}$ (PANOsso et al. 1998) and is separated from the sea by a sand barrier which is about $50 \mathrm{~m}$ wide. It is located in the urban zone and subject to several anthropic impacts, notably the dumping of raw domestic sewage through channels feeding into the lagoon.

The surroundings are partially occupied by residential areas and during the rainy season, flooding of these areas sometimes occurs (BRANCO et al. 1997). The act of artificially opening the sand barrier then causes a drastic drop in the water level, and seawater enters. This artificial opening of the sandbar exposes almost the entire lagoon bed, and results in modifications in the biotic communities (BRANCO 1998, AlberToni et al. 1999, 2001, in press, Palma-Silva et al. 2000, 2002). When the lagoon comes into contact with the ocean, many marine organisms enter, such as the shrimp species $F$. brasiliensis and $F$. paulensis (Penaeidae). Others of continental origin, like $M$. acanthurus (Palaemonidae), use the mesohaline waters for hatching (AlberToni et al. 1999).

\section{MATERIAL AND METHODS}

The analyzed species were collected from the Imboassica lagoon from August 1995 to September 1997. The samplings were carried out at night, one hour after sunset. The night feeding of these species is reported by several authors (LewIs et al. 1966, Hill \& Wassenberg 1987, Wassenberg \& Hill 1987, Primavera \& Lebata 1995, Collins \& Paggi. 1998; Rosemond et al. 1998 , among others). The animals were immediately put on ice, and at the laboratory the stomachs were removed using a dorsal incision in the cephalotorax, and preserved in $70 \%$ ethanol. A total of $495 \mathrm{~F}$. brasiliensis, $131 \mathrm{~F}$. paulensis and 102 M. acanthurus stomachs were analyzed.

The contribution to the total stomach volume of each food item was estimated using the Points Method (Hynes 1950, Windell 1971, Hyslop 1980, Williams 1981). Using the estimate of the volume of the food items and a numerical estimate, the overlap of dietary niches among the three species was calculated by the following methods (KREBS 1989); where:

- Overlap was measured on a scale from 0 (no overlap) to 1 (maximum overlap), expressed as a percentage;

- $\min \left(\mathrm{p}_{\mathrm{i} 1}, \mathrm{p}_{\mathrm{i} 2}\right)=$ smallest proportion of the resource " $\mathrm{i}$ " used comparing species 1 and 2;

- $\mathrm{p}_{\mathrm{i} 1}=$ proportion of resource " $\mathrm{i}$ " in relation to the total resources used by species 1 ;

- $\mathrm{p}_{\mathrm{i} 2}=$ proportion of resource " $\mathrm{i}$ " in relation to the total resources used by species 2 .

a) Percentage Method (Renkonen 1938, in Krebs 1989): $\mathrm{Pm}=$ $\Sigma$ mín $\left(\mathrm{p}_{\mathrm{i} 1}, \mathrm{p}_{\mathrm{i} 2}\right) \times 100$

b) Morisita Method (modified by Horn 1966): $C_{\mathrm{H}}=2 \Sigma \mathrm{p}_{\mathrm{i} 1} \mathrm{p}_{\mathrm{i} 2} /$ $\left.\Sigma \mathrm{p}_{\mathrm{i} 1}{ }^{2}+\Sigma \mathrm{p}_{\mathrm{i} 2}{ }^{2}\right)$

c) MacArthur \& Levins Method (1967): $\mathrm{M}_{12}=\Sigma \mathrm{p}_{\mathrm{i} 1} \mathrm{p}_{\mathrm{i} 2} / \Sigma \mathrm{p}_{\mathrm{i} 1}{ }^{2} \mathrm{e}$ $\mathrm{M}_{21}=\Sigma \mathrm{p}_{\mathrm{i} 1} \mathrm{p}_{\mathrm{i} 2} / \Sigma \mathrm{p}_{\mathrm{i} 2}{ }^{2}$

d) Pianka Method (PIANKA 1973): $\mathrm{O}_{12}=\Sigma \mathrm{p}_{\mathrm{i} 1} \mathrm{p}_{\mathrm{i} 2} / \sqrt{ }\left(\Sigma \mathrm{p}_{\mathrm{i} 1}{ }^{2} \Sigma \mathrm{p}_{\mathrm{i} 2}{ }^{2}\right)$

e) Horn Method (Horn 1966). $\mathrm{R}_{\mathrm{o}}=\left\{\Sigma\left(\mathrm{p}_{\mathrm{i} 1}+\mathrm{p}_{\mathrm{i} 2}\right) \ln \left(\mathrm{p}_{\mathrm{i} 1}+\mathrm{p}_{\mathrm{i} 2}\right)-\left(\Sigma \mathrm{p}_{\mathrm{i} 1} \ln \mathrm{p}_{\mathrm{i} 1}\right)-\left(\Sigma \mathrm{p}_{\mathrm{i} 2} \ln \mathrm{p}_{\mathrm{i} 2}\right)\right\} / 2 \ln 2$
Chesson's electivity index (CHEsson 1978) was applied, comparing the proportion of the food items in the stomachs and the relative abundance of the macrofauna in the two habitats in the Imboassica lagoon occupied by the studied species: the macroinvertebrate community associated with the macroalgae Chara (ALBERTONi et al. 2001), and community of benthic organisms in the sediment, with data presented in Callisto et al. (1998). Chesson's electivity index is measured using the parameter $\mathrm{a}_{\mathrm{i}}$, which estimates the probability of the prey encounter for the capture probability: $\alpha_{\mathrm{i}}=\left(\mathrm{r}_{\mathrm{i}} / \mathrm{p}_{\mathrm{i}}\right) / \Sigma\left(\mathrm{r}_{\mathrm{i}} / \mathrm{p}_{\mathrm{i}}\right)$, where: $\left(r_{i}\right)$ proportion of prey " $i$ " in diet; $\left(p_{i}\right)$ proportion of prey "i" in environment; $\Sigma \alpha_{\mathrm{i}}=1 ;(\mathrm{m})$ number of prey types.

The results are evaluated as follows, when: $\alpha_{\mathrm{i}}=\mathrm{m}^{-1} \rightarrow$ no selective predation occurs; $\alpha_{\mathrm{i}}>\mathrm{m}^{-1} \rightarrow$ selective predation occurs; $\alpha_{\mathrm{i}}<\mathrm{m}^{-1} \rightarrow$ avoidance occurs.

\section{RESULTS}

A total of 25 food items were classified for F. brasiliensis, 17 for F. paulensis, and 20 for M. acanthurus. The results of the frequency of occurrence of the food items demonstrate that, for the peneid species, the predominant items were Polychaeta (Annelida), Heleobia australis (Mollusca: Gastropoda) and Chironomidae (Insecta, Diptera). In the gut content of $M$. acanthurus, the predominant item was detritus, found in $78 \%$ of the analyzed stomaches (Tab. I).

Although there was no significant difference (Friedman, $p>0.05$ ) in the frequencies of occurrence of the alimentary items between the three species, it can be observed that the peneid species present similar occurrences for most of the items, with predominance of Insecta, Mollusca and Anellida while, in $M$. acanthurus larger occurrences of the detritus and Insecta items were found (Tab. I). The overlap of alimentary niches, calculated using the different indexes is presented in table II.

The results indicate a high niche overlap between the two species of Farfantepenaeus, and a lower one between these two species and $M$. acanthurus. The different indexes demonstrate similar results, varying in small units.

The results of the electivity index, related to the fauna associated with Chara (Tab. III) indicate that $F$. brasiliensis preys selectively on Chironomidae, Ostracoda and Tanaidacea, while H. australis, Polychaeta, Amphipoda, Isopoda and Bivalve are present in the diet in a frequency smaller than expected considering its abundance in the environment. Regarding the abundance of benthic fauna on the sediment (Tab. IV), it was found that this species preys selectively on Polychaeta and Chironomidae, found in the diet in higher frequencies than in the environment, and non-selectively on $H$. australis and Bivalve, found in smaller proportions in the diet than in the environment.

The results for $F$. paulensis, in the analyses of the Chara fauna, show selective predation of this species on Tanaidacea and Ostracoda, and non-selective on $H$. australis, Polychaeta, Isopoda, Chironomidae and Amphipoda. For the sediment fauna, selectivity could be seen for Chironomidae, while Polychaeta and $H$. australis were found in smaller proportions in the diet than in the environment.

Macrobrachium acanthurus preys selectively on Odonata and Polychaeta, and non-selectively on Chironomidae, $H$. australis and Ostracoda associated to Chara. In terms of sediment fauna, it also preys selectively on Chironomidae and

Revista Brasileira de Zoologia 20 (1): 135-140, março 2003 
Table I. Frequencies of occurrence of the food items (\%) for the three species for the whole sampling period, August 1995 to September 1997. (N) Stomach number, (empty) total of stomach with no gut content.

\begin{tabular}{|c|c|c|c|c|c|c|c|}
\hline \multirow{3}{*}{$\overline{\text { Insecta }}$} & \multirow{4}{*}{$\begin{array}{l}\text { Items } \\
\text { Chironomidae } \\
\text { Odonata }\end{array}$} & \multicolumn{2}{|c|}{ F. brasiliensis $\mathrm{N}=495$; empty $=39$} & \multirow{2}{*}{\multicolumn{2}{|c|}{$\frac{\text { F. paulensis } \mathrm{N}=131 \text {; empty }=12}{\text { Occurrence }(\%)}$}} & \multirow{2}{*}{\multicolumn{2}{|c|}{$\frac{\text { M. acanthurus } \mathrm{N}=102 ; \text { empty }=3}{\text { Occurrence }(\%)}$}} \\
\hline & & \multicolumn{2}{|c|}{ Occurrence (\%) } & & & & \\
\hline & & 77.40 & 58.580 & 80.9 & 67.94 & \multirow{2}{*}{57.8} & 23.53 \\
\hline & & & 18.790 & & 12.98 & & 32.35 \\
\hline & Coleoptera & & 0 & & 0 & & 1.96 \\
\hline \multirow[t]{3}{*}{ Mollusca } & Heleobia australis & 52.12 & 51.110 & 67.2 & 67.17 & 30.4 & 29.41 \\
\hline & Bivalvia & & 1.010 & & 0 & & 0 \\
\hline & Planorbidea & & 0 & & 0 & & 0.98 \\
\hline \multirow[t]{7}{*}{ Crustacea } & Tanaidacea & 24.80 & 9.690 & 29.8 & 4.58 & 10.8 & 0 \\
\hline & Ostracoda & & 5.050 & & 16.79 & & 5.88 \\
\hline & Isopoda & & 2.820 & & 4.58 & & 0 \\
\hline & Amphipoda & & 6.460 & & 0.76 & & 0 \\
\hline & Cladocera & & 0.800 & & 0 & & 0.98 \\
\hline & Copepoda & & 0.400 & & 0 & & 0 \\
\hline & Cirripedia (larvae) & & 0 & & 0 & & 3.92 \\
\hline \multirow[t]{2}{*}{ Anellida } & Polychaeta & 67.70 & 67.470 & 36.6 & 36.64 & 19.6 & 19.61 \\
\hline & Oligochaeta & & 0.200 & & 0 & & 0 \\
\hline \multirow[t]{3}{*}{ Algae } & Filamentous algae & 11.70 & 9.890 & 9.9 & 6.11 & 44.2 & 12.74 \\
\hline & Chara (frag.) & & 1.010 & & 0 & & 0 \\
\hline & Chara (Oogonium) & & 0.801 & & 3.82 & & 31.37 \\
\hline \multirow[t]{2}{*}{ Pisces } & Fish (scale) & 1.60 & 1.610 & 0.00 & 0 & 27.4 & 25.49 \\
\hline & Fish (bone) & & 0 & & 0 & & 1.96 \\
\hline \multirow[t]{10}{*}{ Others } & Detritus & 14.10 & 12.120 & 8.4 & 9.16 & 45.1 & 78.43 \\
\hline & Foraminifera & & 0.600 & & 0 & & 0 \\
\hline & Insecta (frag.) & & 1.410 & & 0 & & 3.92 \\
\hline & Crustacea (frag.) & & 0.801 & & 0.76 & & 6.86 \\
\hline & Sand & & 0.400 & & 0.76 & & 13.72 \\
\hline & Hydracarina & & 0.200 & & 0.76 & & 0 \\
\hline & Thorn & & 3.830 & & 2.29 & & 1.96 \\
\hline & Schell (frag.) & & 1.210 & & 0 & & 16.67 \\
\hline & Unknown & & 5.650 & & 3.81 & & 1.96 \\
\hline & Rotifera & & 0 & & 3.05 & & 0 \\
\hline
\end{tabular}


Polychaeta, and $H$. australis is found in the diet of this species in smaller frequencies than expected considering the abundance in the environment.

Table II. Niche overlap index: $(\mathrm{Pm})$ minimum percentage, $(\mathrm{CH})$ Morisita modified, (M12 e M 21) MacArthur \& Levins, (O12) Pianka. (RO) Horn, (Fb) Farfantepenaeus brasiliensis, (Fp) F. paulensis, (Ma) Macrobrachium acanthurus.

\begin{tabular}{cccc}
\hline Index & Fb $\times$ Fp & Fb $\times \mathrm{Ma}$ & $\mathrm{Fp} \times \mathrm{Ma}$ \\
\hline $\mathrm{Pm}$ & 75.0 & 32.7 & 31.7 \\
$\mathrm{CH}$ & 89.6 & 32.4 & 25.6 \\
$\mathrm{M} 12$ & 96.1 & 31.3 & 23.2 \\
$\mathrm{M} 21$ & 83.9 & 33.6 & 28.5 \\
$\mathrm{O} 12$ & 89.9 & 32.4 & 25.7 \\
$\mathrm{RO}$ & 93.8 & 57.9 & 55.2 \\
\hline
\end{tabular}

Table III. Electivity index ((i) for macroinvertebrate community associated with Chara in the Imboassica lagoon (ALBERTONI et al. 2001). $\left(^{*}\right)$ Selective predation, $(m-1=1 /$ prey number).

\begin{tabular}{lccc}
\hline \multicolumn{1}{c}{ Items } & F. brasiliensis & F. paulensis & M. acanthurus \\
\hline H. australis & 0.002 & 0.003 & 0.002 \\
Polychaeta & 0.060 & 0.070 & $0.630 *$ \\
Chironomidae & $0.140 *$ & 0.100 & 0.030 \\
Amphipoda & 0.040 & 0.010 & - \\
Isopoda & 0.020 & 0.030 & - \\
Bivalvia & 0.090 & - & - \\
Tanaidacea & $0.390 *$ & $0.170 *$ & - \\
Ostracoda & $0.260 *$ & $0.610 *$ & 0.060 \\
Odonata & - & - & $0.290 *$ \\
m - 1 & 0.125 & 0.143 & 0.200 \\
\hline
\end{tabular}

Table IV. Electivity index $\left(\alpha_{i}\right)$ for benthonic community in the Imboassica lagoon (CALLISTO et al. 1998). (*) Selective predation (m$1=1 /$ prey number).

\begin{tabular}{lccc}
\hline \multicolumn{1}{c}{ Items } & F. brasiliensis & F. paulensis & M. acanthurus \\
\hline H. australis & 0.160 & 0.23 & 0.07 \\
Polychaeta & $0.430 *$ & 0.21 & $0.42 *$ \\
Chironomidae & $0.400 *$ & $0.56 *$ & 0.51 * \\
Bivalvia & 0.002 & - & - \\
$\mathrm{m}-1$ & 0.250 & 0.33 & 0.33 \\
\hline
\end{tabular}

\section{DISCUSSION}

Although some authors classify the Penaeidae as detritivores (DALL 1968), it has been shown that their diet is extremely diverse. Diversified diets, with several elements of the benthic community, have been observed by many authors (Edwards 1978, Chong \& Sazekumar 1981, Tararam et al. 1993, Cartes 1995, Dittel et al. 1997, Albertoni et al. in press).

For Palaemonidae species, many authors have shown that they also have a diet made up of a number of different items, although detritus is usually an important and quite common component (Howard 1984, Collins \& PAGgi 1998). According AlBERTONi et al. (in press), in the Imboassica lagoon M. acanthurus also shown omnivore characteristics, with several items of this nature found, including insects (larvae of Chironomidae and nymphs of Odonata), fish remains - the scales and some bones for example, Chara oogonium and polychaetes. The most common item, however, was detritus. Due to the diversified diet found for both Penaeidae and Palaemonidae, several studies were developed aiming to clarify the role of these consumers in the regulation of the meso and macrofauna of aquatic environments (Bell \& Coull 1978, StePHENSON 1980; Nelson 1981, Leber 1985, Nelson \& Capone 1990, Posey \& Hynes 1991, Butler et al. 1992, Rosemond et al. 1998).

It is to be expected that species which use similar resources such as food and space in an environment have a high degree of overlap while species that use different resources have a low overlap index (LuDwig \& Reynolds 1988). In theory, the overlap of niches is considered one possible determinant of the structure and diversity of communities (Petraitis 1979). From the obtained results, it can be confirmed that high overlap occurs between the two species of Farfantepenaeus, and among the peneids species and M. acanthurus the overlap is smaller.

Studies of niche overlap are not related to competition (ABrams 1980, LAWLOR 1980). The authors point out that overlap refers to the use of the same resource type for two or more species, happening when some level of use of the resource exists for the two species. The overlap measure does not imply competition because, if the resources are abundant, competition does not exist regardless of the overlap degree (ABRAMs 1980).

Several indexes for analysis of niche overlap are found in the literature, and there is controversy over which provides the best answer. According to HurLbert (1978), the selection of an index should be made in function of how easy biological interpretation is and its capacity of taking into account the variation in the availability of resources.

As verified in the analyses of the frequency of occurrence and relative volume of the food items, the resources used by the three species are similar. Thus, the analyses of overlap of the alimentary niches provide us with a more precise idea of the use of the existent food resources to be found in the Imboassica lagoon. In the present study, the calculations of niche overlap, using several indexes, showed the same tendency. This makes it possible to suggest that the determination of the overlap of alimentary niches for the evaluated species of the Imboassica lagoon does not depend on the used index. Together with the measures of niche overlap, the electivity index helps us to discover more about the predator species in the environment. Application of electivity measures is rare, particularly for crustacean decapods, because it presupposes a 
quantification of the resources in the environment used by the species, something which is rarely done. Chara is an abundant macroalgae in the Imboassica lagoon, reaching a high biomass (PALMA-Silva et al. 2002) occupying most of the limnetic region of the lagoon. It is one of the habitats of the studied species, and it shelters a community which represents the main food items of the analyzed shrimps (АlвERTONI et al. 2001). In environments where they occur, the carophytes have an abundant associated community of meso and macrofauna (Higler 1981, Hanson 1990, Kairesalo et al. 1992, Oertli 1995, among others).

In the Imboassica lagoon, Chara shelters a rich and dense macroinvertebrate community. The gastropod $H$. australis is responsible for $80 \%$ of the total abundance, with a mean density of $22846 \mathrm{org} / \mathrm{m}^{2}$ (AlberToNi et al. 2001) and mean proportions of $51 \%$ in the fauna sediment (CALLisTo et al. 1998). Nonselectivity on this gastropod is probably due to its high density in the two studied habitats. Although it was frequent and abundant in the analyzed stomaches, in none of the species was this gastropod was found in very high frequencies. The three species did not therefore present selective predation on this organism.

Other items, such as Chironomidae larvae, Polychaeta and crustaceans, occured in lower densities in the macroalgae, presenting different electivity degrees. From the results, it can be suggested that the studied species have a good available food supply in the Imboassica lagoon, and probably select prey that provide the most energy and has the fewest hard parts, such as the shell of gastropods.

It is believed that the obtained estimates are valid for analysing the trophic relationship of the species studied in the environment, due to the great difficulty of observing their feeding behavior in situ. The results obtained with the analysis of the diet of F. brasiliensis, F. paulensis and M. acanthurus make it possible to verify the role of these species, which act as important predators of elements of the benthic fauna and of that associated with aquatic macrophytes in the Imboassica lagoon.

The dietary niches of $F$. brasiliensis and $F$. paulensis have a high overlap, and there is a smaller overlap between each one of these species and $M$. acanthurus, indicating a similarity in the feeding habits of the peneids and differences between theirs and those of the paleomonid. The results of the overlap of the alimentary niches showed the same tendency, regardless of the used index, indicating that none of them are more efficient than the others for this evaluation between the studied species.

The electivity results show that the species select some prey in the spectrum of food resources provided by the environment. From the preliminary evaluations of density of both the benthic communities and those associated with the macroalgae Chara and the growth indexes, mainly of peneid species, it can be inferred that the Imboassica lagoon is an environment where food is not a stress factor. This conclusion could serve as a basis for the elaboration of plans for the integrated management of this ecosystem and the development of extensive cultive programs of some species (ALBERTONI 1998).

\section{ACKNOWLEDGMENTS}

The authors thank CAPES, CNPq and PETROBRAS for the financial support.

\section{REFERENCES}

Abrams, P. 1980. Some comments on measuring niche overlap. Ecology, Durham, 61 (1): 44-49

Albertoni, E.F. 1998. Camarões da lagoa Imboassica: dados preliminares e perspectivas de manejo, p. 359-371. In: F.A. EsTeves (Ed.). Ecologia das Lagoas Costeiras do Parque Nacional da Restinga de Jurubatiba e do Município de Macaé (RJ). Rio de Janeiro, NUPEM/UFRJ, 464p.

Albertoni, E.F.; C. Palma-Silva; F.A. Esteves. 1999. Larvae and postlarvae of Penaeidae and Palaemonidae in coastal lagoons of the north of Rio de Janeiro (Macaé, RJ). Revista Brasileira de Biologia, Rio de Janeiro, 59 (1): 109-117

. 2001. Macroinvertebrates associated with Chara in a tropical coastal lagoon (Imboassica Lagoon, Rio de Janeiro, Brazil). Hydrobiologia, Dordrecht, 457: 215-234

- 2002 (in press). Natural diet of three species of shrimp in a tropical coastal lagoon (Imboassica lagoon, RJ, Brazil). Brazilian Archives of Biology and Technology, Curitiba.

BELL, S.S. \& B.C. Coull. 1978. Field evidence that shrimp predation regulates meiofauna. Oecologia, Berlin, 35: 141-145

Branco, C.W.C. 1998. Composição e aspectos ecológicos das comunidades zooplanctônicas nas lagoas Imboassica, Cabiúnas e Comprida, p. 247-271. In: F.A. Esteves. (Ed.). Ecologia das Lagoas Costeiras do Parque Nacional da Restinga de Jurubatiba e do Município de Macaé (RJ). Rio de Janeiro, NUPEM/UFRJ, 464p.

Branco, C.W.C.; T. Aguiaro; F.A. Esteves \& E.P. Caramaschi. 1997. Food sources of the teleost Eucinostomus argenteus in two costal lagoons of Brazil. Studies in Neotropical Fauna \& Environment, Lisse, 32: 33-40

Butler, R.S.; E.J. Moyer; M.W. Hulon \& V.P. Williams. 1992. Littoral zone invertebrate communities as affected by a habitat restoration project on lake Tohopekaliga, Florida. Journal of Freshwater Ecology, London, 7 (3): 317-328

Callisto, M; J.F.JR Gonçalves; J.J.F. Leal \& M.M. Petrucio. 1998. Macroinvertebrados bentônicos nas lagoas Imboassica, Cabiúnas e Comprida, p. 283-298. In: F.A. Esteves (Ed.). Ecologia das Lagoas Costeiras do Parque Nacional da Restinga de Jurubatiba e do Município de Macaé (RJ). Rio de Janeiro, NUPEM/UFRJ, 464p.

CARTES, J.E. 1995. Diets of, and trophic resources exploited by, bathyal penaeiodean shrimps from the western Mediterranean. Marine and Freshwater Research, London, 46: 889-896.

CHesson, J. 1978. Measuring preference in selective predation. Ecology, Durham, 59 (2): 211-215.

Chong, V.C. \& A. SAzerumar. 1981. Food and feeding habitats of the white prawn Penaeus merguiensis. Marine Ecology Progress Series, Amelinghausen, 5: 185-191.

Collins, P.A. \& J.C. PAGgi. 1998. Feeding ecology of Macrobrachium borelli (Nobili) (Decapoda: Palaemonidae) in the flood valley of the river Paraná, Argentina. Hydrobiologia, Dordrecht, 362: 21-30.

DALL, W. 1968. Food and feeding of some Australian penaeid shrimp. FAO Fisheries Technical Reports, Rome, 57 (2): 251-258.

Dittel, A.; C.E. Epifanio; L.A. Cifuentes \& D.L. Kirshman. 1997. Carbon and nitrogen sources for shrimp postlarvae fed on natural diets from a tropical mangrove system. Estuarine,

Revista Brasileira de Zoologia 20 (1): 135-140, março 2003 
Coastal and Shelf Science, London, 45: 629-637.

EDWARDS, R.R.C. 1978. Ecology of a coastal lagoon complex in Mexico. Estuarine, Coastal and Shelf Science, London, 6: 75-92

Hanson, J.M. 1990. Macroinvertebrate size-distributions of two contrasting freshwater macrophyte communities. Freshwater Biology, London, 24: 481-491

Heales, D.S.; D.J. Vance \& N.R. Loneragan. 1996. Field observations of moult cycle, feeding behavior, and diet of small juvenile tiger prawns Penaeus semisulcatus in the Embley River, Australia. Marine Ecology Progress Series, Amelinghausen, 145: 43-51

HigLer, L.W.G. 1981. Bottom fauna and littoral vegetation fauna in lake Maarsseveen. Hydrobiological Bulletin, London, 15: $82-87$

Hill, B.J. \& T.J. Wassenberg. 1987. Feeding behavior of adult tiger prawns, Penaeus esculentus, under laboratory conditions. Australian Journal of Marine and Freshwater Research, London, (38): 183-190.

Horn, H.S. 1966. Measurement of "overlap" in comparative ecological studies. The American Naturalist, Chicago, 100 (914): 419-424

HowARD, R.K. 1984. The trophic ecology of caridean shrimps in na eelgrass community. Aquatic Botany, Amsterdam, 18: 155-174

HurlberT, S.H. 1978. The measurement of niche overlap and some relatives. Ecology, Durham, 59 (1): 67-77.

Hynes, H.B.N. 1950. The food of fresh-water sticklebacks (Gasterosteus aculeatus and Pygosteus pungitius), with a review of methods used in studies of the food of fishes. Journal of Animal Ecology, London, 19: 36-57.

HysLop, E.J. 1980. Stomach contents analysis - a review of methods and their application. Journal of Fish Biology, London, 17: 411-429.

Kairesalo, T.; G. Jónsson; K. Gunnarsson; C. Lindegaard, \& P.M. JónASSON. 1992. Metabolism and community dynamics within Nitella opaca (Charophyceae) beds in Thingvallavatn. Oikos, Copenhagen, 64: 241-256.

Krebs,C. J. 1989. Ecological Methodology. New York, Harper \& Row, 654p.

LAWLOR, L.R. 1980. Overlap, similariry, and competition coefficients. Ecology, Durham, 61 (2): 245-251.

LEBER, K.M. 1985. The influence of predatory decapods, refuge, and microhabitat selection on seagrass communities. Ecology, Durham, 66 (6): 1951-1964.

Lewis, J.B.; J WARD; A. MCIVER. 1966.The breeding cycle, growth and food of the fresh water shrimp Macrobrachium carcinus (Linnaeus). Crustaceana, Leiden, 10 (1): 48-52.

Ludwig, J.A. \& J.F. REYNoLDS. 1988. Statistical Ecology. New York, John Wiley \& Sons, 337p.

MacArthur, R.H. \& R. Levins. 1967. The limiting similarity, convergence, and divergence of coexisting species. The American Naturalist, Chicago, 101: 377-385.

Nelson, W.G. 1981. Experimental studies of decapod and fish predation on seagrass macrobenthos. Marine Ecology Progress Series, Amelinghausen, 5: 141-149.

Nelson, W.G. \& M.A. Capone. 1990. Experimental studies of predation on polychaetes associated with seagrass beds.
Estuaries, Columbia, 13 (1): 51-58.

OERTLI, B. 1995. Spatial and temporal distribution of the zoobenthos community in a woodland pond (Switzerland). Hydrobiologia, Dordrecht, 300/301: 195-204.

Palma-Silva, C; E.F. Albertoni \& F.A. Esteves. 2000. Eleocharis mutata (L.) Roem. Et Schult. subject to drawdowns in a tropical coastal lagoon, State of Rio de Janeiro, Brazil. Plant Ecology, Dordrecht, 148: 157-164.

2002.The role of charophytes primary production in a coastal lagoon subjected to human impacts (RJ, Brazil). Acta Limnologica Brasiliensia, São Paulo, 14 (1): 59-69.

Panosso, R.F.; J.L. Attayde \& D. Muehe. 1998. Morfometria das lagoas Imboassica, Cabiúnas, Comprida e Carapebus: Implicações para seu funcionamento e manejo, p. 91-108. In: F.A. Esteves (Ed.). Ecologia das Lagoas Costeiras do Parque Nacional da Restinga de Jurubatiba e do Município de Macaé (RJ). Rio de Janeiro, NUPEM/UFRJ, 464p.

Petraitis, P.S. 1979. Likelihood measures of niche breadth and overlap. Ecology, Durham, 60(4): 703-710

PianKa, E.R. 1973. The structure of lizard communities. Annual Review of Ecology and Systematics, Stanford, 4: 53-74.

Posey, M.H. \& A.H. HyNes. 1991. Complex predator-prey interactions within an estuarine benthic community. Ecology, Durham, 72 (6): 2155-2169.

Preston, N.P.; M.A. Burford; F.E. Coman \& P.C. Rothlisberg. 1992. Natural diet of larval Penaeus merguiensis (Decapoda: Penaeidae) and its effect on survival. Marine Biology, Berlin, 113: 181-191.

Primavera, J.H. \& J. Lebata. 1995. Diel activity patterns in Metapenaeus and Penaeus juveniles. Hydrobiologia, Dordrecht, 295: 295-302.

RADAMBRASIL. 1983. Levantamento de Recursos Naturais. Rio de Janeiro/Vitória: geologia, geomorfologia, pedologia, vegetação e uso potencial da terra. Rio de Janeiro, Ministério de Minas e Energia, folhas SF.23/24p.

Rosemond, A.D.; C.M. Pringle \& A. Ramirez. 1998. Macroconsumer effect on insect detritivores and detritus processing in a tropical stream. Freshwater Biology, London, 39: 515-523.

Stephenson, W. 1980. Relationship of the macrobenthos of Moreton Bay to prawns and to abiotic factors. Australian Journal of Ecology, Adelaide, 5: 143-149.

Tararam, A. S.; Y. Wakabara \& M.B. EqüI. 1993. Hábitos alimentares de onze espécies da megafauna bêntica da plataforma continental de Ubatuba, SP. Publicação Especial do Instituto Oceanográfico, São Paulo, 10: 159-167.

Wassenberg, T.J. \& B.J Hill. 1987. Natural diet of the tiger prawns Penaeus esculentus and P. semisulcatus. Australian Journal of Marine and Freshwater Research, Adelaide, 38: 169182.

Williams, M.J. 1981. Methods for analysis of natural diet in portunid crabs (Crustacea: Decapoda: Portunidae). Journal of Experimental Marine Biology and Ecology, Amsterdam, 52: 103-113

WINDELL, J.T. 1971. Food analysis and rate of digestion, p. 215226. In: W.E. RICKER (Ed.). Methods for assessment of fish production in fresh waters. London, IBP, 348p.

Recebido em 05.IX.2002; aceito em 14.III.2003. 